\title{
Comparative analysis of design models for concrete corbels
}

\section{Análise comparativa de modelos de cálculo para consolos de concreto}

D. L. ARAÚJO a

dlaraujo@ufg.br

A. P. SILVA NETO antonioneto117@hotmail.com

F. A. LOBO faustinhoalobo@gmail.com

M. K. EL DEBS b mkdebs@sc.usp.br

\begin{abstract}
The main objective of this paper is performing a comparative analysis of some design models for precast concrete corbels. For this, it was analyzed design models from Brazilian (NBR 9062) and European (EUROCODE 2) Codes and a US design handbook (PCI). Moreover, three analytical models showed in the literature are analyzed. The objective of this comparative is identifying the best design models to represent the failure load of concrete corbels by the tie yields or by the concrete crushing. Moreover, it is intended to evaluate the contribution of horizontal stirrups to resistance of concrete corbels. For this, a database was assembled from test results of concrete corbels carried out by several researchers and they are showed in the literature. The design models were applied to this database and from statistical tools, adjustments coefficients are recommended to be applied on these design models to take into account the results dispersion found in the analysis.
\end{abstract}

Keywords: corbels, precast concrete, design models, horizontal stirrup.

\section{Resumo}

O objetivo deste trabalho é realizar uma análise comparativa de alguns modelos de cálculo para consolos de concreto pré-moldado. Para isso, são analisados os modelos de cálculo das normas brasileiras (NBR 9062) e europeia (EUROCODE 2) e de um manual de projeto norte-americano (PCl). Além disso, são analisados três modelos de cálculo sugeridos na literatura. Busca-se nessa comparação identificar os modelos que melhor representam a força de ruína dos consolos, seja pelo escoamento do tirante ou pelo esmagamento do concreto da biela. Além disso, busca-se identificar a contribuição da armadura de costura na resistência do consolo. Para isso, foi montado um banco de dados a partir de resultados de ensaios de consolos de concreto realizados por diversos pesquisadores presentes na literatura, no qual os modelos em questão foram aplicados. Utilizando-se de ferramentas estatísticas, são definidos coeficientes de ajustes a serem aplicados aos modelos para uso em projeto e que levam em conta a dispersão de resultados encontrada na análise.

Palavras-chave: consolos, concreto pré-moldado, modelos de cálculo, armadura de costura.

Universidade Federal de Goiás, Goiânia, GO, Brasil;

Universidade de São Paulo, São Carlos, SP, Brasil.

Received: 17 Feb 2015 • Accepted: 05 Jan 2016 • Available Online: 31 May 2016 


\section{Introduction}

The use of precast concrete has been gradually growing and this has driven improvements in design methods for precast structures. This growth has occurred due to the advantages of using this construction process. When using precast elements there is a significant reduction in the construction time, while precast concrete elements have better workmanship and better quality control and may often be incorporated in a building without significant aesthetic impact.

One of most common precast elements is the corbel, which is a structural element that protrudes perpendicularly from columns and serves to support other structural elements such as beams and slabs. Despite the concrete corbel being a commonly used element there are different design methods that lead to different reinforcement arrangements.

Usually the design of corbels can be simplified using the strut-and-tie method. This simplification is possible because tension and compression zones arise in corbels which can be modeled like a truss. In the tension zones steel ties are placed to resist the tensile forces and compressive struts are represented by concrete between cracks. While not as concentrated as in the tie region, there are also some tension zones along the corbel height. In this case some Codes recommend placing supplementary horizontal stirrups along the corbels to combat these tensile stresses.

For this analysis we selected the immediately applicable codes i.e. the Brazilian Code ABNT NBR 9062 [1] and the European Code EUROCODE 2 [2]. The strut-and-tie method shown in the PCl design handbook [3] was also analyzed due to the wide application of this handbook in the design of precast concrete structures. These three are design methods. These publications recommend slightly different methods for the tie design. However, the main difference between them is the different approaches to the verification of the compressive strut. Further, they do not consider the supplementary horizontal stirrups in their formulation, despite the fact that ABNT NBR 9062 and EUROCODE 2 require a minimum amount of reinforcement by horizontal stirrups.

Due to the absence of suitable design methods the horizontal stirrups in strut-and-tie designs are often treated as part of the tension ties as in ABNT NBR 9062. Therefore, in addition to the design methods shown in the codes and manuals, three analytical approaches, formulated with the inclusion of horizontal stirrup reinforcement, were analyzed. The first is an adaptation proposed by Fernandes and El Debs [4] of the classic method showed by Leonhardt and Mönnig [5]. The second is an adaptation of the method proposed by Hagberg [6] and the third method was proposed by Campione et al. [7]. These three are analytical methods.

Using statistical tools, adjustment coefficients were calculated for application in the design of concrete structures. These coefficients take into account the dispersion of results observed when comparing the various design methods, using a database assembled from the experimental results available in the literature [8-21]. This database consists of 62 short corbels designs (with a/d ratio between 0.5 and 1.0 ) with concrete compressive strengths ranging from $25 \mathrm{MPa}$ to $105 \mathrm{MPa}$. Finally, only corbels tested without the presence of horizontal force were considered.

\section{Design methods for Corbels}

The design methods shown in codes and manuals are intended

\section{Figure 1 - (a) Truss geometry and (b) width of strut from the ABNT NBR 9062 (1) design method}

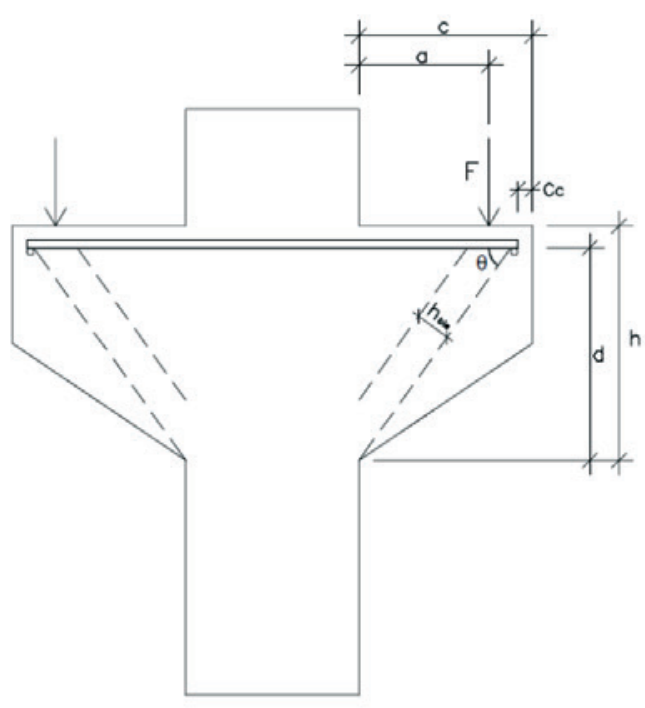

A

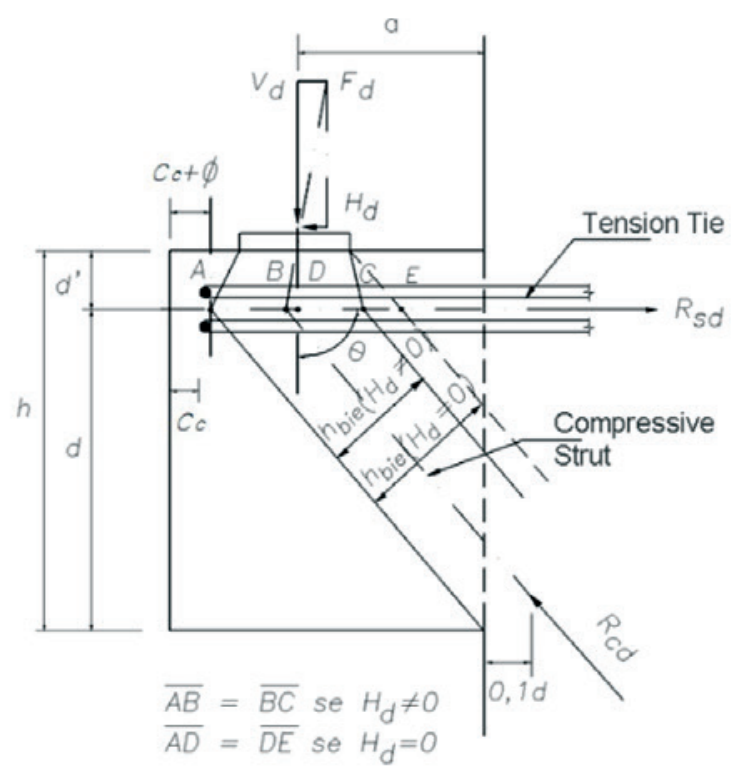

B 
for use by those designing concrete structures. Therefore, these equations are formulated in such a way as to give the amount of tie reinforcement required based on the factored force on the corbel and on its geometry. After this the compressive strut is verified to avoid concrete crushing. However, for the purpose of analyzing the accuracy of each method its equations must be modified to make it possible to obtain the maximum force on a corbel based on its geometry, amount of tie reinforcement and compressive concrete strength. In this way this force can be compared to the maximum strength of corbels present in the experimental database i.e. the strength limited by either the yield point of the tension tie or the concrete crushing limit on the compressive strut.

This section lays out the equations obtained from the six design methods chosen for analysis. The first three methods are based on strut-and-tie technology and provide a fixed geometry for the truss without considering the presence of the horizontal stirrups. The other three analytical methods chosen consider the presence of the horizontal stirrups in the corbel resistant mechanism formulation. In the first two analytical methods, horizontal stirrups are considered by modifying the position of the tension tie so that it forms an alternative truss. The compressive strut is taken to have a constant width. The third analytical method proposes a secondary truss formed by horizontal stirrups that resists part of the force applied on the corbel. In this method the strut width varies as a function of the balance of bending moments on the corbel.

\subsection{ABNT NBR 9062 design method}

The first design method analyzed is the Brazilian Code ABNT NBR 9062 [1] for the design and execution of precast concrete structures. In this the corbel is modeled by the strut-and-tie method shown in Figure 1a. In this method failure may occur by the yielding of the tension tie or by the crushing of the compressive strut. This method does not cover the design of the nodal zone of the truss. According to ABNT NBR 9062 the area of the tension tie $\left(A_{s}\right)$ is determined by equation (1)

$$
A_{s}=\left(0,1+\frac{a}{d}\right) \frac{V_{d}}{f_{y d}}
$$

where $a$ is the distance from the vertical load applied to the corbel and column face, $d$ is the distance from extreme compression fiber to centroid of tension tie, $V_{d}$ is the factored vertical load and $f_{y d}$ is the steel yielding stress.

Equation (2) can be used to determine the failure load of the corbel by yield of the tension tie $\left(V_{d}\right)$ using the known geometry of the corbel, the yield steel strength and tie steel area.

$$
V_{d}=\frac{A_{s} f_{y d}}{\left(0,1+\frac{a}{d}\right)}
$$

For the compression strut the Code ABNT NBR 9062 proposes the geometry shown in Figure $1 \mathrm{~b}$. From this geometry the maximum force $\left(V_{d}\right)$ due to the weight of concrete on the compressive strut can be determined by equation (6) using the corbel's dimensions and concrete strength. This equation is obtained from equation (3), where the value of the force in the strut $\left(F_{b i e}\right)$ was determined by multiplying the concrete strength $\left(f_{c d}\right)$ by the area of the compression strut.

$$
F_{b i e}=\frac{V_{d}}{\sin \theta}
$$

$$
f_{c d} b(l \sin \theta)=\frac{V_{d}}{\sin \theta}
$$

$$
V_{d}=f_{c d} b 2\left(c-a-\phi-c_{c}\right) \sin ^{2} \theta
$$

$$
V_{d}=\frac{2 f_{c d} b d^{2}\left(c-\phi-c_{c}-a\right)}{d^{2}+\left(c-c_{c}-\phi\right)^{2}}
$$

where $\theta$ is the angle of compressive strut, $b$ is the corbel width and $c$ is the corbel length. The mean of other variables is shown on Figure 1b.

\subsection{EUROCODE 2 design method}

The second studied design method is that recommended by Eurocode 2 [2] which has adopted the strut-and-tie method shown in Figure $2 \mathrm{a}$. The simplified method shown in Figure $2 \mathrm{~b}$ is given for the short corbel design which makes it equivalent to the method in the ABNT NBR 9062 code with the addition of node 1 resistance verification [22].

Working out the balance of the forces on truss of Figure $2 \mathrm{~b}$ and imposing the additional requirement of the maximum compression stress at a nodal zone, gives equation (7) for calculating the failure load due to the yielding of the tension tie corbel and equation (8) for calculating the failure load due to the crushing of concrete in the compression strut.

$$
V_{d}=\sqrt{\left[a b k_{1}\left(1-\frac{f_{c d}}{250 \times 10^{6}}\right) \frac{f_{c d}}{\gamma_{c}}\right]^{2}+1,6 b d f_{y d} A_{s} k_{1}\left(1-\frac{f_{c d}}{250 \times 10^{6}}\right) \frac{f_{c d}}{\gamma_{c}}}-a b k_{1}\left(1-\frac{f_{c d}}{250 \times 10^{6}}\right) \frac{f_{c d}}{\gamma_{c}}
$$




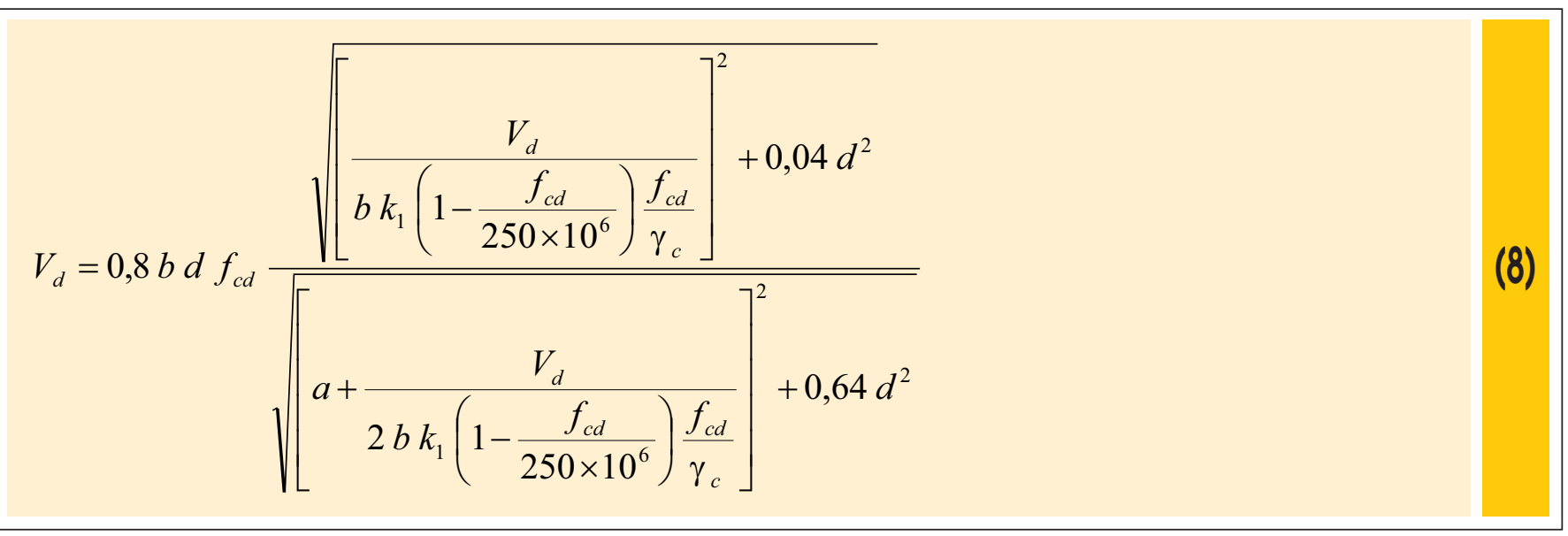

where $k_{1}$ is the EUROCODE 2 constant, that is 1.18 , and $\gamma_{c}$ : is the strength reduction factor for concrete.

\section{$2.3 \mathrm{PCl}$ design method}

The third method studied is the strut-and-tie design method recommended by the $\mathrm{PCl}$ design handbook [3]. This is represented by the truss shown in Figure $3 a$. In the case of double corbels, this method can be modified obtaining the truss shown in Figure $3 \mathrm{~b}$. The method shown in Figure $3 a$ differs from that recommended by ABNT NBR 9062 and EUROCODE 2 in dealing with a truss with a larger number of elements. These are an upper tension tie NO, on the corbel, and tension ties MN and MP, on the column. Moreover, two compression struts NP and OP appear. However, in the double corbel only one compression strut appears on each side. Thus this method reduces to that recommended by the other two Codes. The $\mathrm{PCl}$ design method includes the nodal zone verification requirement. Looking at the equilibrium of loads on the truss of Figure $3 a$ or Figure $3 \mathrm{~b}$, and checking the maximum compression stress at a nodal zone $p$, we obtain the distance $w_{s}$ that defines the geometry of the truss:

$$
w_{s}=\frac{V_{d}}{0,85 \gamma \beta_{n} b f_{c d}}
$$

In this equation, $\beta_{n}$ is the coefficient recommended by the $\mathrm{PCl}$, that is: 1.0 for a nodal zone that receives only compressive forces; 0.8 for a nodal zone with one tie; 0.6 for a nodal zone with more than one tie. Using this equation on equation (10), the maximum force on the corbel $\left(V_{d}\right)$ can be determined from its dimensions $(b, d$ and a), the yield strength of the tie steel $\left(f_{y}\right)$, the concrete compression strength $\left(f_{c d}\right)$ and the area of upper tension tie $\left(A_{s}\right)$, as shown on Equation 12.

$$
A_{s}=\frac{F_{t i r}}{\gamma f_{y}} \Rightarrow V_{d}=A_{s} \gamma f_{y} \tan \theta \Rightarrow V_{d}=\frac{A_{s} \gamma f_{y} d}{a+\frac{V_{d}}{2 \times 0,85 \gamma \beta_{n} b f_{c d}}}
$$

$V_{d}^{2}+1,7 \gamma \beta_{n} b f_{c d} a V_{d}-1,7 A_{s} f_{y} d \gamma^{2} \beta_{n} b f_{c d}=0$
$\therefore$

$$
V_{d}=\frac{\sqrt{\left(1,7 \gamma \beta_{n} b f_{c d} a\right)^{2}+6,8 A_{s} f_{y} d \gamma^{2} \beta_{n} b f_{c d}}-1,7 \gamma \beta_{n} b f_{c d} a}{2}
$$


Figure 2 - (a) Truss geometry of EUROCODE 2 (2) and (b) simplified geometry

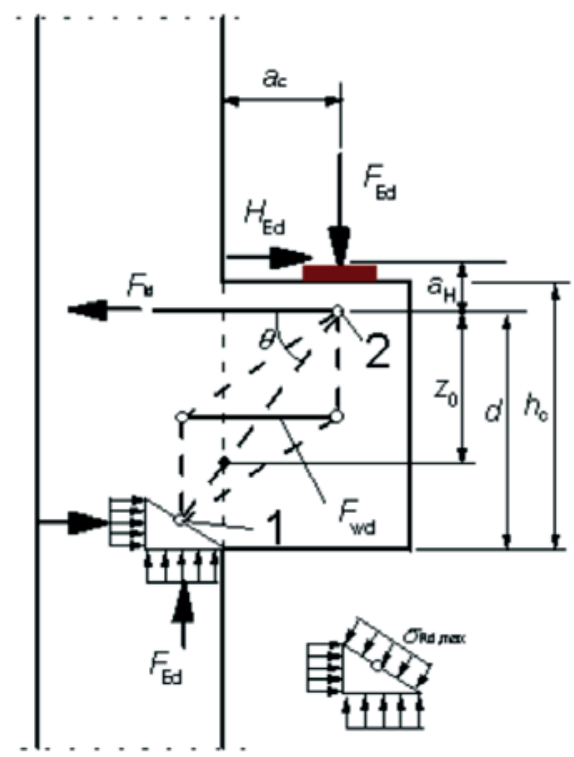

A

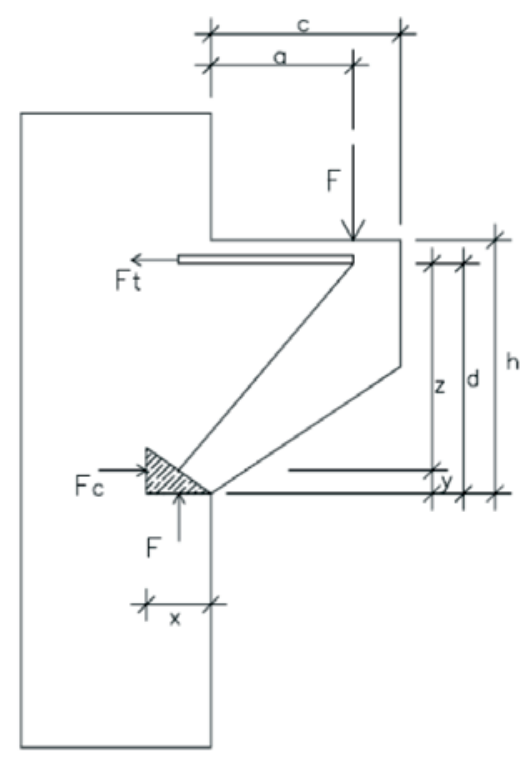

B

Figure 3 - (a) Truss geometry of the PCI (3) design method and (b) adapting for a double corbel

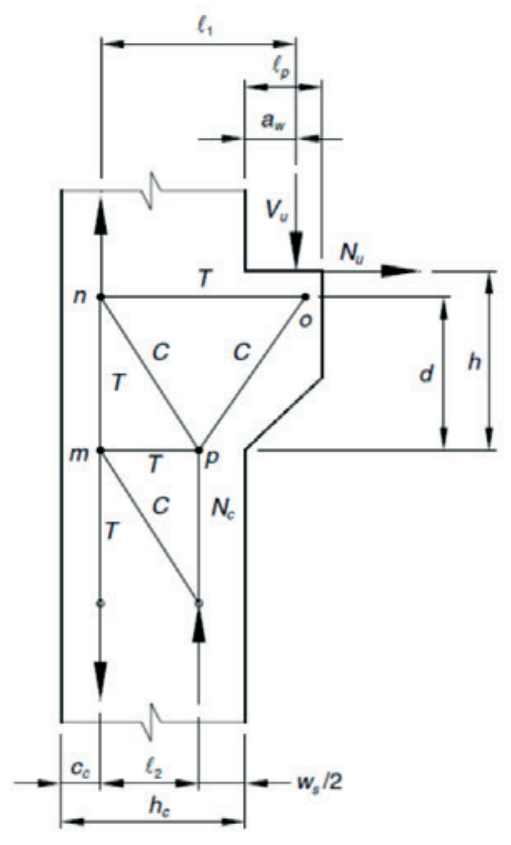

A

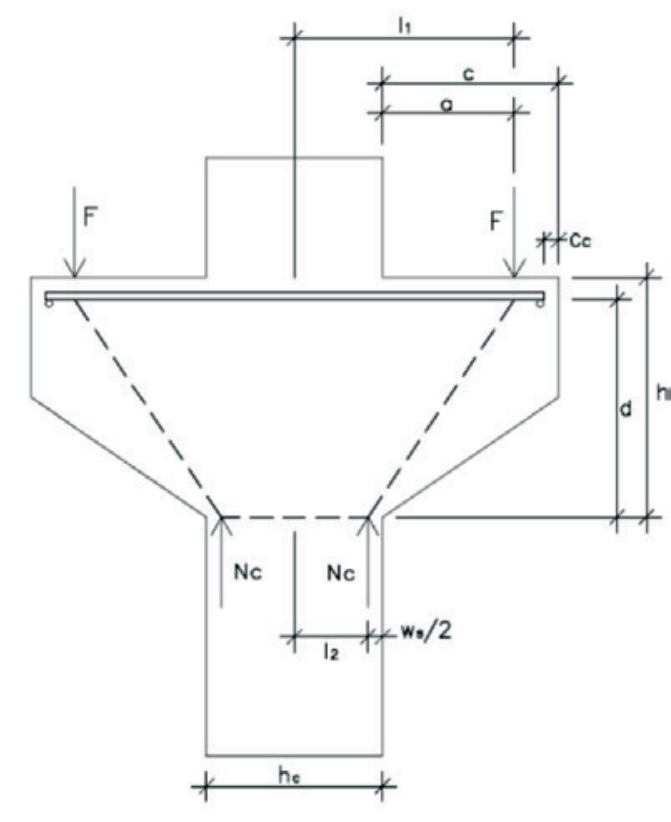

B 
In the case of failure by the crushing of the concrete of compression strut OP, equation (13) is obtained for the maximum load. This equation was obtained assuming that the nodal zone at point $\mathrm{P}$ presents a right angled triangle form, as laid out in the $\mathrm{PCl}$ [3]. When a general triangle is considered equation (14) is obtained. This equation applies only to the OP compression strut and not to the NP compression strut as all corbels present in the database are double and therefore do not include the NP compression strut (Figure 3b).

$$
V_{d}=0,85 \gamma \beta_{s} f_{c d} b d^{2} \frac{\left[\left(h_{c}-c_{c}\right)-\sqrt{\left(h_{c}-c_{c}\right)^{2}-\frac{2 V_{d}\left(a+h_{c}-c_{c}\right)}{0,85 \gamma \beta_{n} f_{c d} b}}\right]}{d^{2}+\left[a+\sqrt{\left(h_{c}-c_{c}\right)^{2}-\frac{2 V_{d}\left(a+h_{c}-c_{c}\right)}{0,85 \gamma \beta_{n} f_{c d} b}}\right]^{2}}
$$

$$
\left.V_{d}=\frac{0,425 \gamma \beta_{n} f_{c d} b}{\left(a+h_{c}-c_{c}\right)}\left[\left(h_{c}-c_{c}\right)^{2}-\frac{d^{2}}{\left(\frac{\beta_{n}{ }^{2}}{\beta_{s}{ }^{2}}+1\right)+\left[\frac{\left(2 a+h_{c}-c_{c}\right)}{2 d}-\sqrt{\left(\frac{h_{c}-c_{c}}{2 d}\right)^{2}-V_{d} \frac{\left(a+h_{c}-c_{c}\right)}{1,7 \phi f_{c d} b \beta_{n} d^{2}}}\right.}\right]^{2}\right]
$$

In these equations, $h_{c}$ is the width of column, $c_{c}$ is the concrete covering at the end of the tension tie and $\beta_{\mathrm{s}}$ is the coefficient recommended by the $\mathrm{PCl}$, that is: 0.6 for corbels without horizontal stirrups and 0.75 for corbels with horizontal stirrups.

\subsection{Design method proposed by Fernandes and El Debs}

The fourth design method analyzed is proposed by Fernandes and El Debs [4]. In this case the authors start from the method presented by Leonhardt and Mönnig [5] and rewrite the equations in order to take into account the contribution of horizontal stirrups located in the region of $2 d / 3$ from the top of the corbel (Figure 4). This limitation of height is due to the fact that horizontal stirrups outside this range have a very small deformation, not contributing to the corbel strength.

The maximum force on the corbel limited by the yield of the tension tie is calculated as in equation (15). The indices " $i$ " represent the number of layers of horizontal bars including the tie. This equation was modified from the original work to allow for the fact that not all horizontal stirrups reach the yield strength. For this reason, a weighting factor, defined by the ratio of the distance of each bar to the base of the corbel $\left(d_{i}\right)$ and the corbel height $(d)$, was introduced. This fact is demonstrated in [16] which shows that, when the tension tie yields, the other horizontal stirrups below the tie remain within their elastic range.

$$
\begin{gathered}
V_{d}=\sum_{i=1}^{n} A_{s i} f_{y d i} \frac{z_{i}}{a} \frac{d_{i}}{d} \\
z_{i}=0,9 d_{i}
\end{gathered}
$$

In the case of failure by crushing of the compression strut, equation (16) gives the maximum force on the corbel. It was assumed that the width of the compression strut was equal to $0.2 d$ as originally presented by Leonhardt and Mönnig [5].

$$
V_{d}=\frac{0,18 f_{c d} b d^{*}}{\sqrt{0,9^{2}+\left(\frac{a}{d^{*}}\right)^{2}}}
$$

$$
d^{*}=\sum_{i=1}^{n} \frac{d_{i} R_{s d i}}{R_{s d}}
$$

$$
\begin{aligned}
& R_{s d i}=A_{s i} f_{y d i} \\
& R_{s d}=\sum_{i=1}^{n} R_{s d i}
\end{aligned}
$$




\subsection{Haglberg design method}

The method proposed by Hagberg [6] is similar to the method proposed by Leonhardt and Mönnig and also considers the contribution of the horizontal stirrups. The difference in these methods is the inclusion of a notional position where the tension tie and all horizontal reinforcement located at a height of $2 d / 3$ from the top of the corbel was concentrated. This is the equivalent height $d^{*}$ shown in Figure 5. The maximum vertical load of the corbel, when the failure is by tension tie yield, is given by equation (19):

$$
V_{d}=\sum_{i=1}^{n} A_{s t i} f_{y d i} \frac{z_{i}}{a^{*}}
$$

\section{Where:}

$$
a^{*}=0,5\left[a+\sqrt{a^{2}+d^{* 2} \omega^{*}\left(2-\omega^{*}\right)}\right]
$$

$$
d^{*}=\sum_{i=1}^{n} \frac{d_{i} R_{s d i}}{R_{s d}}
$$

$$
\begin{aligned}
& R_{s d i}=A_{s i} f_{y d i} \frac{d_{i}}{d} \\
& R_{s d}=\sum_{i=1}^{n} R_{s d i}
\end{aligned}
$$

$$
\omega^{*}=\sum_{i=1}^{n} \frac{A_{s i} f_{y d i}}{b d^{*} f_{c d}^{*}}
$$

$$
f_{c d}^{*}=0,85\left(1-\frac{f_{c k}}{250}\right) f_{c d}
$$

$$
z_{i}=d_{i}-0,5 \omega^{*} d^{*}
$$

Equation (22), which represents the equivalent resultant tie force $\left(R_{\text {sdi }}\right)$, was also modified here. This was to allow for the fact that

\section{Figure 4 - Fernandes and El Debs (4) analytical method based on the method presented by Leonhardt e Mönnig (5)}

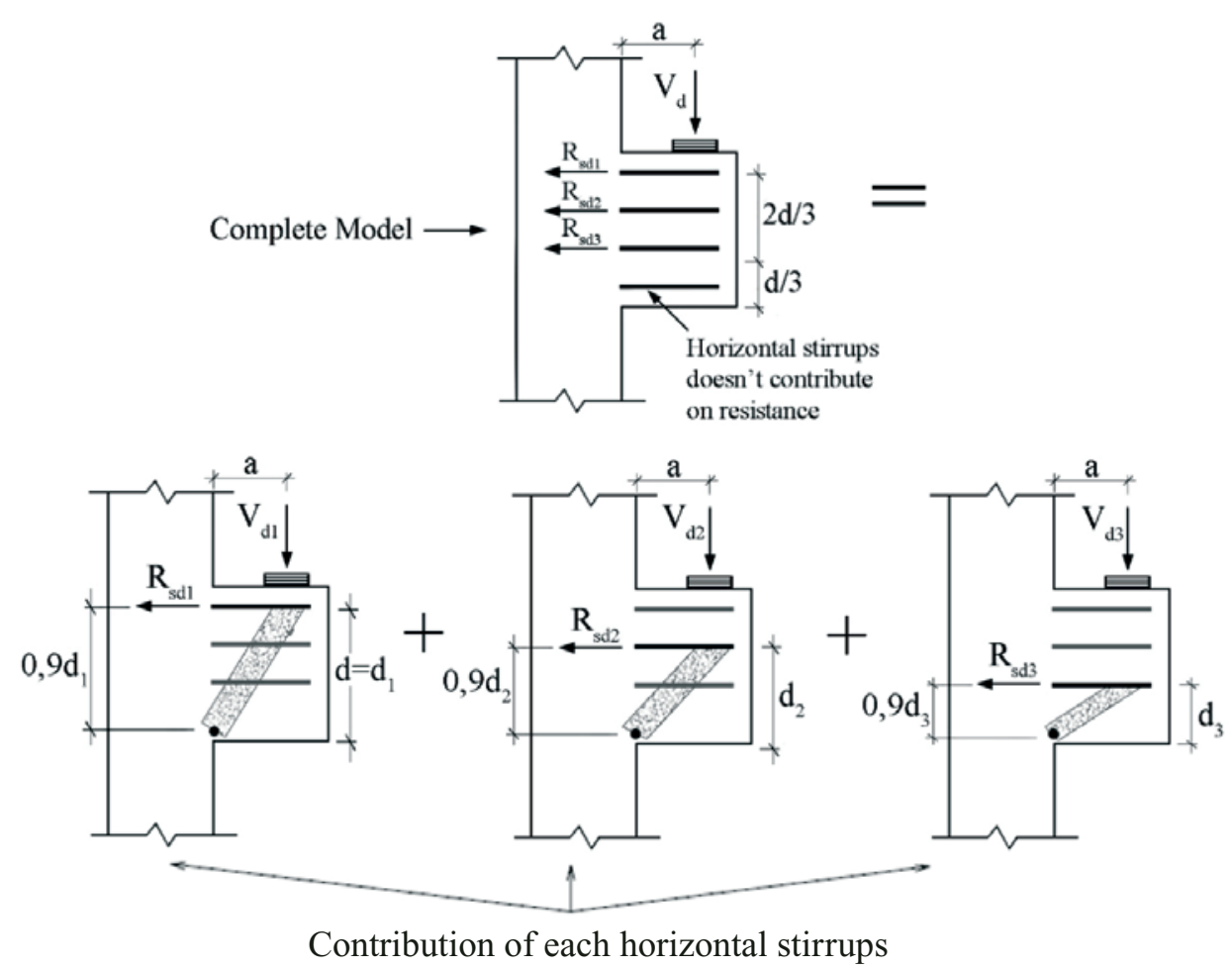




\section{Figure 5 - Hagberg (6) analytical method}
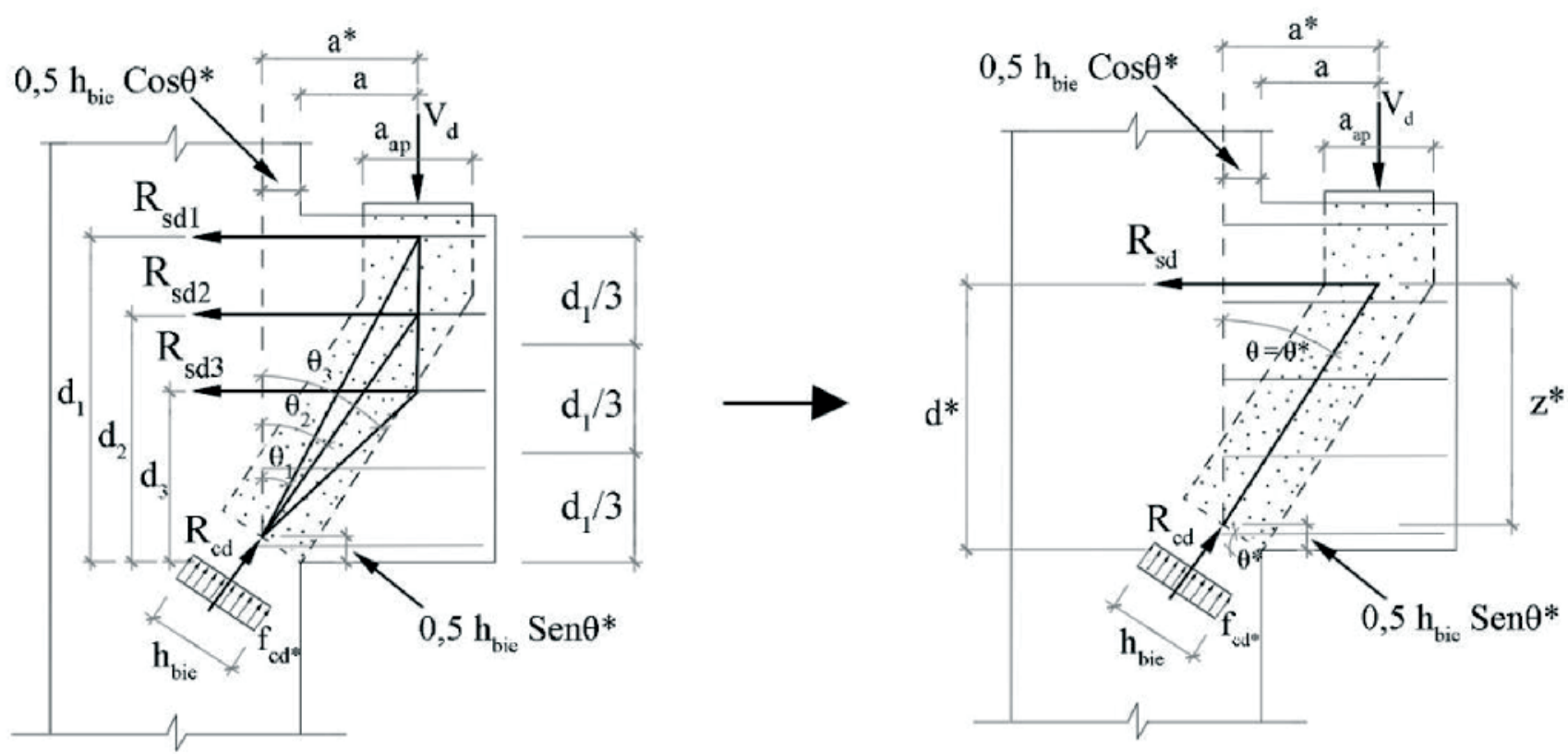

the force resisted by each bar is proportional to the ratio of the distance from the bar to the base of the corbel $\left(d_{i}\right)$ and to the height of the corbel $(d)$.

When corbel failure occurs by the crushing of a compression strut the force on the strut is given by equation (26), where the $a_{b i e}$ value is shown in equation (27).

$$
R_{c d}=\frac{V_{d} a^{*}}{a_{b i e}}
$$

With:

$$
\begin{gathered}
a_{b i e}=\frac{a^{*}}{\sqrt{1+\left(\frac{a^{*}}{z^{*}}\right)^{2}}} \\
z^{*}=d^{*}-0,5 \omega^{*} d^{*}
\end{gathered}
$$

The compressive stress on the strut is:

$$
\sigma_{c d}=\frac{R_{c d}}{h_{b i e} b}
$$

From equations (26) and (28), the maximum vertical load $V_{d}$, on the corbel due to compression strut failure is given by equation (29).

$$
V_{d}=\frac{f_{c d} h_{b i e} b a_{b i e}}{a^{*}}
$$

In this equation $h_{b i e}$, the required width of the compression strut, can be calculating according to either of the two main design recommendations. If we adopt the strut width as recommended by ABNT NBR 9062 [1], equation (30) is obtained:

$$
h_{b i e}=\frac{2 d^{*}\left(c^{\prime}-a\right)}{\sqrt{d^{* 2}+c^{\prime 2}}}
$$

If we use the Leonhardt and Mönnig [5] recommendation, that is, $h_{\text {bie }}$ equal to $0.2 \mathrm{~d}$, then equation (31) is obtained.

$$
V_{d}=\frac{0,2 f_{c d} b d^{*} a_{b i e}}{a^{*}}
$$


Substituting the value of $a_{\text {bie }}$ as given in equation (27), into equation (29), and using two different values for $h_{b i e}$ we get:

$$
V_{d}=\frac{0,2 f_{c d} b d^{*}}{\sqrt{1+\left(\frac{a^{*}}{z^{*}}\right)^{2}}}
$$

$$
V_{d}=\frac{2 f_{c d} b d^{*}\left(c^{\prime}-a\right)}{\sqrt{1+\left(\frac{a^{*}}{z^{*}}\right)^{2}} \sqrt{d^{* 2}-c^{\prime 2}}}
$$

Equation (32) is for a strut of width equal to $0.2 d$, and equation (33) is for a strut whose width is estimated from the Brazilian Code ABNT NBR 9062 [1].

\subsection{Campione et al. design method}

Campione et al. [7] propose two design methods for corbels: one is for corbels without horizontal stirrups and other for corbels with horizontal stirrups. For corbels without horizontal stirrups balancing is carried out for the simplified truss bars shown in Figure 6. From the balance of forces on the bars and the mechanical strength of the materials, the equations for calculating the maximum force of corbel limited by tension tie yield, equation (34), and limited by crushing concrete on the compression strut, equation (35), are determined:

$$
V_{d}=f_{y d} A_{s} \tan \alpha
$$

$$
V_{d}=\xi f_{c}^{\prime} b x_{c} \cos \alpha \sin \alpha
$$

where $\alpha$ is the angle of compressive strut and $f_{c}^{\prime}$ is the specified compressive strength of concrete. The depth of neutral axis $\left(x_{c}\right)$ can be determined by equation (36) and the $\xi$ coefficient, which estimates the compression strut strength decrease due to the normal tension stresses, can be determined by equation (37).

$$
x_{c}=\left(\sqrt{A_{s}^{2}+\frac{2 E_{c} b A_{s} d}{E_{s}}}-A_{s}\right) \frac{E_{s}}{b E_{c}} ; E_{c}=4700 \sqrt{f_{c}}
$$

$$
\xi=\frac{5,8}{\sqrt{f_{c}}} \frac{1}{\sqrt{1+400 \varepsilon_{r}}} \leq \frac{0,9}{\sqrt{1+400 \varepsilon_{r}}} ; \varepsilon_{r}=\frac{f_{y}}{E_{s}}
$$

As regards the corbels with horizontal stirrups, Campione et al. [7] propose a notional secondary truss to represent the resultant of forces in the horizontal stirrups. In this case, the vertical force acting on the corbel is divided between the two trusses according to the stiffness of each. Thus a coefficient $\eta$ can be defined, based on the rigidity of the main truss $\left(R_{1}\right)$ and secondary truss $\left(R_{2}\right)$, which represents the portion of the applied force on the corbel which is supported by the main truss. Using this force, it is possible to estimate the maximum force on the corbel that will cause a failure by tension tie yield, equation (41), or by the crushing of concrete on the compression strut of the main truss, equation (42).

\section{Figure 6 - Campione et al. (7) analytical method}

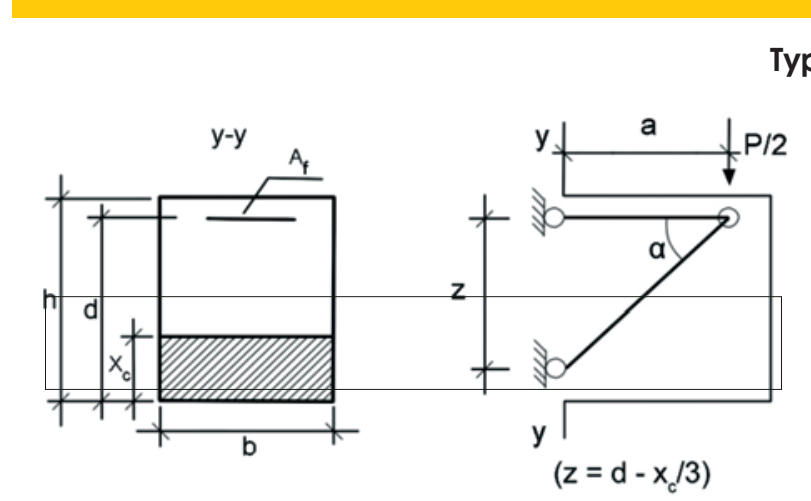

A)

\section{Types of corbel}
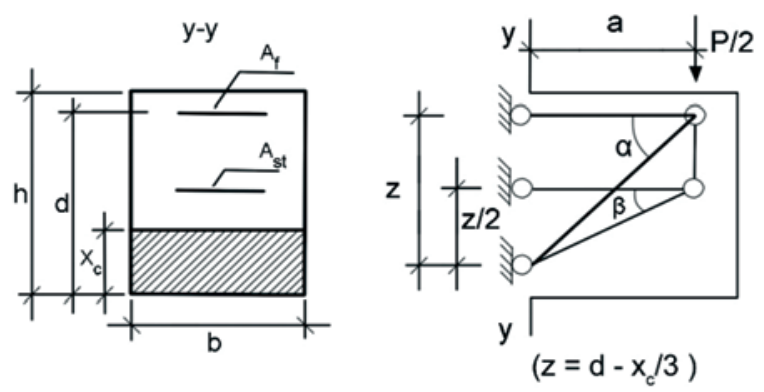

B Corbel with horizontal stirrups 


$$
\begin{aligned}
R_{1} & =\frac{1}{\frac{a}{E_{s} A_{f 1} \tan ^{2} \alpha}+\frac{\sqrt{a^{2}+z^{2}}}{E_{c} A_{c 1} \sin ^{2} \alpha}} \\
A_{c 1} & =b x_{c} \cos \alpha
\end{aligned}
$$

$$
\begin{aligned}
R_{2}= & \frac{1}{\frac{a}{E_{s} A_{f 2} \tan ^{2} \beta}+\frac{\sqrt{a^{2}+z / 2}}{E_{c} A_{c 2} \sin ^{2} \beta}} \\
A_{c 2} & =b x_{c} \cos \beta
\end{aligned}
$$

$$
\eta=\frac{R_{1}}{R_{1}+R_{2}}
$$

$$
V_{d}=\frac{1}{\eta} f_{y d} A_{s} \tan \alpha
$$

$$
V_{d}=\frac{1}{\eta} \xi f_{c}^{\prime} b x_{c} \cos \alpha \sin \alpha
$$

\section{Results and discussion}

The equations deduced in the previous section were used to estimate the maximum force on the corbels in the database and this force was compared with the experimental results in order to assess the accuracy of the design methods. In assembling this database, we attempted to identify, in each paper, the corbel geometry and the materials properties (concrete and steel) - information necessary in all of the design methods. For each corbel we discussed the maximum force based on tie failure (considered by yield of the tension tie) considerations on concrete crushing of the compressive strut. The database was divided into two groups, one of corbels without horizontal stirrups and other of corbels with horizontal stirrups. The maximum force predicted by each of the design methods was calculated with and without the strength reduction and/or load factors defined in each method.

\subsection{Comparison between design methods}

Figure 7 shows the variation of the resistant force by six methods for a short corbel with a/d ratios ranging from 0.5 to 1.0. For this analysis we adopted the geometry, reinforcement ratio and material properties of corbel 26 tested by Fattuhi [8].

In the design methods described [1-3] horizontal stirrups were not taken into consideration. In the analytical methods [4, 6 and 7$]$ horizontal stirrups were considered when calculating the maximum

\section{Figure 7 - (a) Estimated failure load from tension tie and (b) compressive strut on a hypothetical corbel}

\section{Tension tie failure}

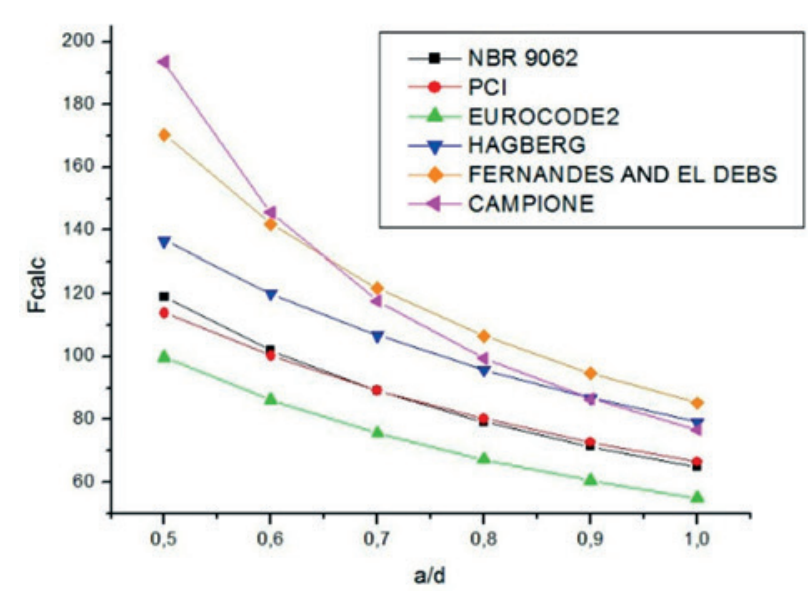

A

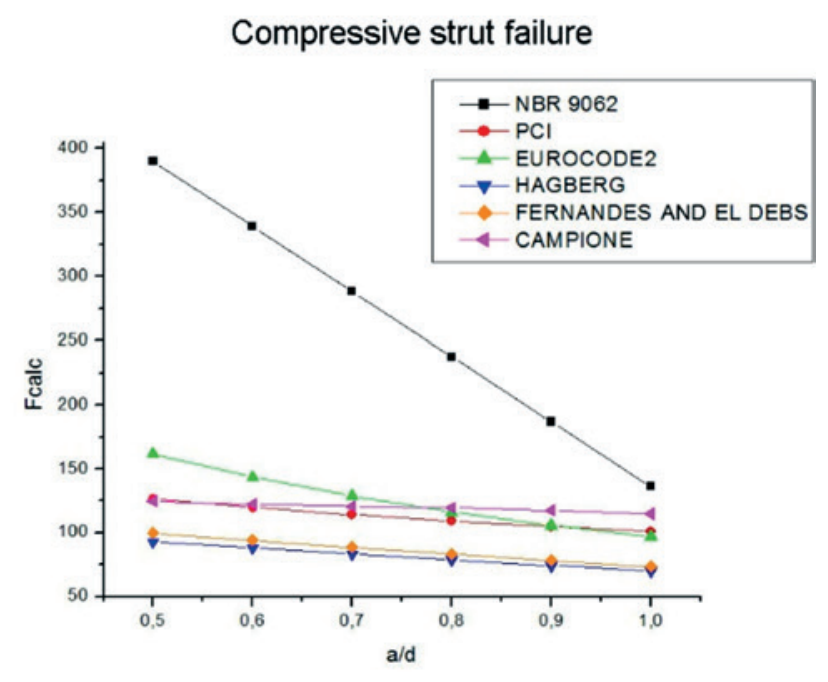

B 
force. In the methods proposed by Fernandes and El Debs [4] and Hagberg [6] based on the work of Leonhardt and Mönnig [5], the maximum force limited by the failure of the compressive strut was calculated using a strut width equal to $0.2 d$. In the case of the method proposed by Campione et al. [7], it was used $\xi$ coefficient as proposed in the original article.

It can be seen in Figure 7a that, for tie failure, the methods predict similar behaviors and that the force assessed by PCI [3] and ABNT NBR 9062 [1] are almost coincident. The maximum force calculated taking horizontal stirrups into account [1-3] is higher than that obtained from methods without horizontal stirrups [4-6]. Finally, the curves all have similar shapes i.e. the difference between the different methods remains approximately constant as we vary the ratio $\mathrm{a} / \mathrm{d}$, except in the method proposed by Campione et al. [7] where the maximum force falls off more steeply with increasing $\mathrm{a} / \mathrm{d}$.

In Figure $7 \mathrm{~b}$ a similar behavior can be seen for all of the methods, with the exception of the ABNT NBR 9062 [1] method, when failure occurred as a result of crushing of the compressive strut. In all but the latter the a/d ratio has very little effect on the maximum force. The reason for this difference in behavior appears to be that the width of strut as specified by ABNT NBR 9062 [1] is excessive.

From this analysis it can be seen that the method of Eurocode 2 [2] is the most conservative in estimating the tie failure load and the methods of Fernandes and El Debs [4] and Hagberg [6] are the most conservative in estimating the compressive strut failure load. However, the main point of this analysis was to illustrate the difference between results from different design methods. This can help to better assess concrete corbels design methods.

\subsection{Assessment of design methods}

A summary of the application of the ABNT NBR 9062 [1], Eurocode 2 [2] and $\mathrm{PCl}[3]$ design methods for the corbels in the database is shown in Table 1. This table shows the average and standard deviation of the ratio between experimental maximum force $\left(F_{\text {exp }}\right)$ and the maximum force predicted by each of the design methods $\left(F_{\text {calc }}\right)$. In this case, the failure force of the design methods was calculated with and without the strength reduction and/or load factors defined in each method. Furthermore, the average values and not the characteristic values for the resistance of concrete and steel were used. The analysis is performed for failure by tension tie yielding and by concrete crushing on the compressive strut.
The ratio between failure forces obtained from design methods and experimental results from database is shown graphically in Figure 8. The ratio $\mathrm{F}_{\text {exp }} / \mathrm{F}_{\text {calc }}$ obtained from tie failure with various cross sectional areas is shown in Figures $8 \mathrm{a}$ and $8 \mathrm{~b}$ and the ratio $\mathrm{F}_{\text {exp }} / \mathrm{F}_{\text {calc }}$ from failure of the compression strut with various concrete compressive strengths is shown in Figures $8 \mathrm{c}$ and $8 \mathrm{~d}$.

Initially, the analysis is made without consideration of strength reduction and/or load factors set for each method. From Table 1, it can be seen that for corbels without horizontal stirrups, if the failure occurs by the tie yielding, the ABNT NBR 9062 [1] method is the closest to the experimental results (average difference of $4 \%$ ). However, the EUROCODE 2 [2] method is more conservative (average difference of $32 \%$ ). The average difference between the results of the design methods recommended by ABNT NBR 9062 [1] and the $\mathrm{PCl}[3]$ was only $3 \%$, indicating that both methods accurately represent the experimental results.

Analyzing failure by tie yielding of corbels with horizontal stirrups, a substantial increase in the resistance of corbels due to the presence of the horizontal stirrups is noted. In this case all three design methods provide lower values than those observed in the database, the $\mathrm{PCl}$ [3] design method being the one closest to the experimental values (average difference of $20 \%$ ) and the EUROCODE 2 [2] design method the most conservative (average difference of $67 \%$ ). It is worth remembering that these design methods do not take into account the effect of the horizontal stirrups on the resistance of the corbels. This explains the $\mathrm{F}_{\text {exp }} / \mathrm{F}_{\text {calc }}$ ratio increase when horizontal stirrups were added to corbels. In fact, previous studies have shown that the presence of horizontal stirrups can increase the strength of a corbel by $30 \%$ to $50 \%$ when compared to the same corbel without this reinforcement. [23]

Making a hypothesis test on the $\mathrm{F}_{\text {exp }} / \mathrm{F}_{\text {calc }}$ ratio obtained from tie yielding failure, with a $95 \%$ confidence band, it is concluded that this ratio is significantly equal to 1.0 for the ABNT NBR 9062 [1] and $\mathrm{PCl}$ [3] design methods. Thus it can be concluded that these design methods accurately estimate the strength of corbel without horizontal stirrups when failure occurs by tie yielding. On the other hand, this ratio is significantly different from 1.0 for the EUROCODE 2 [2] design method. The same hypothesis test was applied to corbels with horizontal stirrups and it is concluded that these design methods don't accurately estimate the strength of corbel with horizontal stirrups when failure occurs by tie yielding.

Analyzing the resistance of corbels without horizontal stirrups

Table 1 - Comparison of design methods with experimental results of database $\left(\mathrm{F}_{\text {exp }} / \mathrm{F}_{\text {calc }}\right)$

\begin{tabular}{c|ccccccc} 
Corbel & Failure mode & $\begin{array}{c}\text { ABNT NBR } \\
9062(1)\end{array}$ & $\begin{array}{c}\text { ABNT NBR } \\
9062(1) \text { with } \\
\text { strength } \\
\text { reduction } \\
\text { factor }\end{array}$ & PCI (3) & $\begin{array}{c}\text { PCI (3) with } \\
\text { strength } \\
\text { reduction } \\
\text { factor }\end{array}$ & $\begin{array}{c}\text { EUROCODE } \\
2(2)\end{array}$ & $\begin{array}{c}\text { EUROCODE } \\
2 \text { (2) with } \\
\text { strength } \\
\text { reduction } \\
\text { factor }\end{array}$ \\
$\begin{array}{c}\text { Without } \\
\text { horizontal } \\
\text { stirrups }\end{array}$ & Tie & $0.96 \pm 0.14$ & $1.54 \pm 0.23$ & $0.93 \pm 0.13$ & $1.74 \pm 0.24$ & $1.32 \pm 0.18$ & $2.03 \pm 0.28$ \\
$\begin{array}{c}\text { With } \\
\text { horizontal } \\
\text { stirrups }\end{array}$ & Strut & $0.83 \pm 0.47$ & $1.63 \pm 0.92$ & $1.07 \pm 0.43$ & $1.99 \pm 0.80$ & $0.84 \pm 0.50$ & $1.88 \pm 1.11$ \\
\hline
\end{tabular}


Figure 8 - Comparison of design methods with experimental results of database
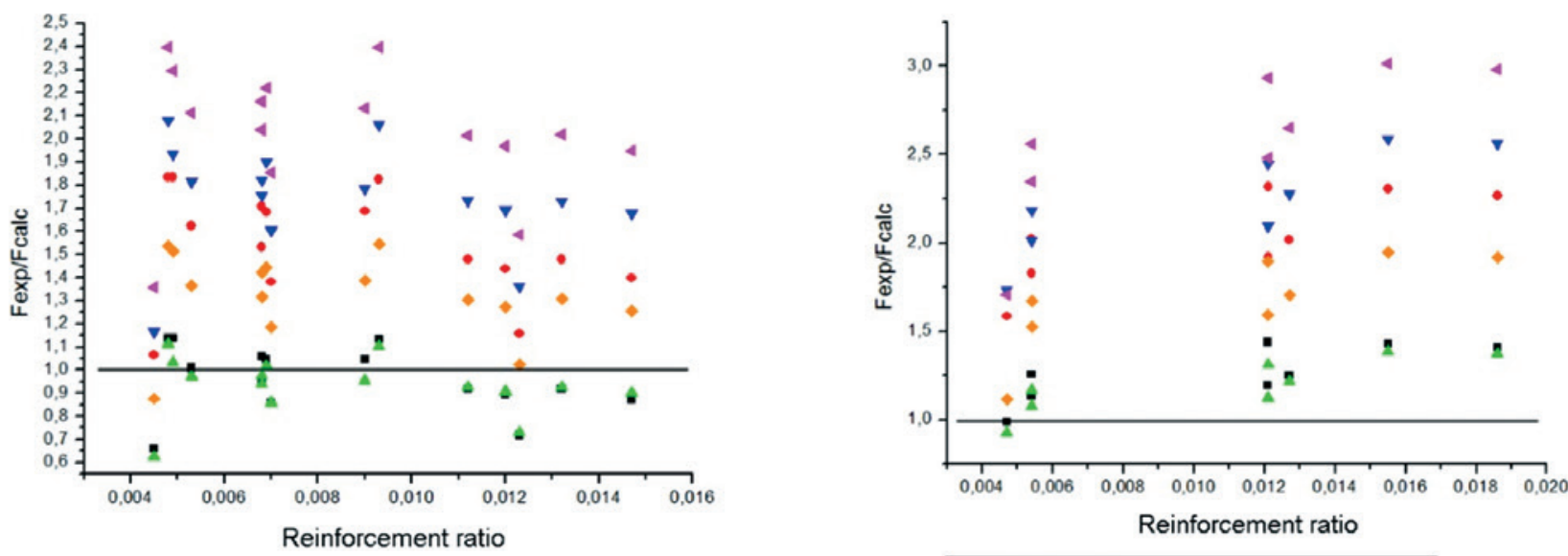

- NBR 9062

- NBR 9062 with partial safety factors

$\triangle \mathrm{PCl}$

$\nabla \mathrm{PCl}$ with strength reduction factors

- EUROCODE2

4 EUROCODE2 with partial safety factors

- NBR 9062

- NBR 9062 with partial safety factors

$\triangle \mathrm{PCl}$

$\checkmark \mathrm{PCl}$ with strength reduction factors

- EUROCODE2

EUROCODE2 with partial safety factors

A Corbels without horizontal stirrups with failure on tension tie

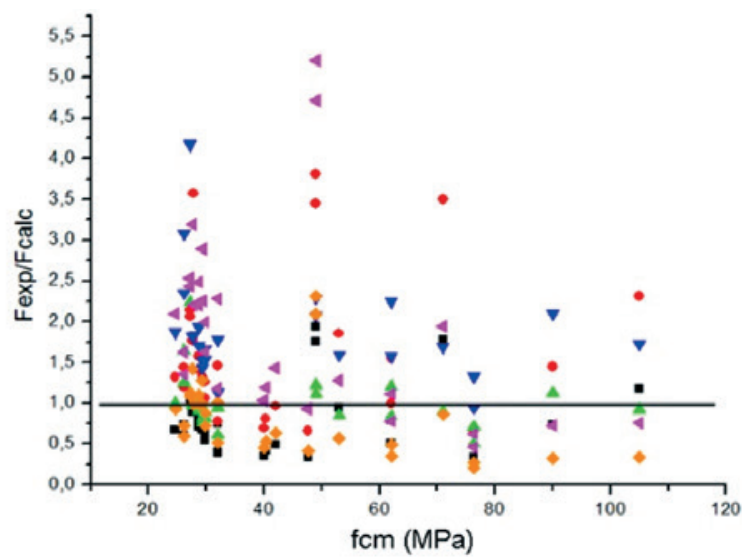

- NBR 9062

- NBR 9062 with partial safety factors

- $\mathrm{PCl}$

$\checkmark \mathrm{PCl}$ with strength reduction factors

- EUROCODE2

4 EUROCODE2 with partial safety factors

C Corbels without horizontal stirrups with failure on compressive strut
B Corbels with horizontal stirrups with failure on tension tie

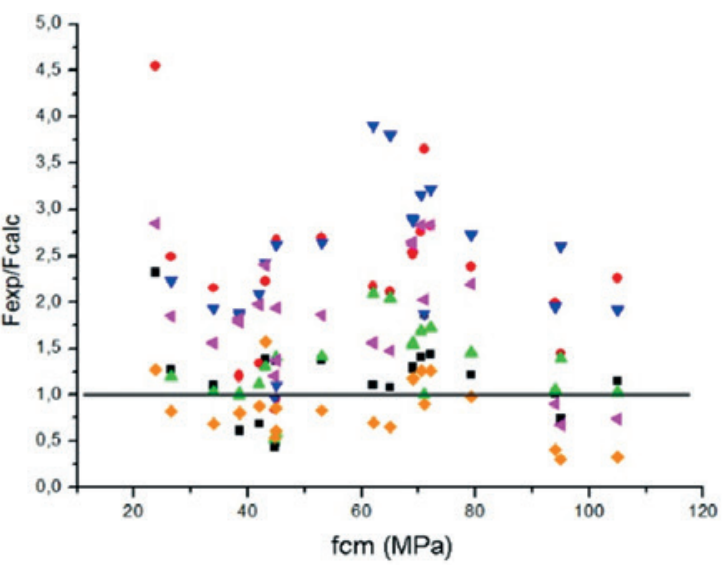

NBR 9062

- NBR 9062 with partial safety factors

$\triangle \mathrm{PCl}$

$\nabla \mathrm{PCl}$ with strength reduction factors

- EUROCODE2

4 EUROCODE2 with partial safety factors

D Corbels with horizontal stirrups with failure on compressive strut 


\section{Table 2 - Comparison of analytical methods with experimental results of database $\left(F_{\text {exp }} / F_{\text {calc }}\right)$}

\begin{tabular}{|c|c|c|c|}
\hline \multirow{2}{*}{\multicolumn{2}{|c|}{ Analytical method }} & \multicolumn{2}{|c|}{ Failure mode } \\
\hline & & Tie & Strut \\
\hline \multirow{2}{*}{$\begin{array}{l}\text { Hagberg (6) for corbels } \\
\text { with horizontal stirrups }\end{array}$} & $h_{\text {bie }}=0.2 d$ & \multirow{2}{*}{$0.96 \pm 0.09$} & $1.48 \pm 0.45$ \\
\hline & $h_{\text {bie }}$ from NBR 9062 & & $1.23 \pm 0.51$ \\
\hline \multirow{2}{*}{$\begin{array}{l}\text { Fernandes and El Debs (4) for } \\
\text { corbels with horizontal stirrups }\end{array}$} & $h_{\text {bie }}=0.2 d$ & \multirow{2}{*}{$0.91 \pm 0.10$} & $1.35 \pm 0.43$ \\
\hline & $\mathrm{h}_{\text {bie }}$ from NBR 9062 & & $1.13 \pm 0.45$ \\
\hline \multirow{2}{*}{$\begin{array}{l}\text { Campione et al. (7) for corbels } \\
\text { without horizontal stirrups }\end{array}$} & $\xi=1$ & \multirow{2}{*}{$0.96 \pm 0.13$} & $0.85 \pm 0.26$ \\
\hline & $\xi$ from article & & $1.05 \pm 0.28$ \\
\hline \multirow{2}{*}{$\begin{array}{l}\text { Campione et al. (7) for } \\
\text { corbels with horizontal stirrups }\end{array}$} & $\xi=1$ & \multirow{2}{*}{$0.78 \pm 0.06$} & $1.04 \pm 0.56$ \\
\hline & $\xi$ from article & & $1.44 \pm 0.90$ \\
\hline
\end{tabular}

when failure occurs by concrete crushing on the compressive strut, it can be seen from Table 1 that the design methods recommended by ABNT NBR 9062 [1] and the EUROCODE 2 [2] may be unsafe. The design method recommended by the $\mathrm{PCl}$ [3] seems to be more precise and safe, with an average difference of $7 \%$ compared to the experimental results. However, a high standard deviation was seen in the analysis of the compressive strut failure.

Analyzing the resistance of corbels with horizontal stirrups when failure occurs by concrete crushing of the compressive strut, the method of ABNT NBR 9062 [1] is shown to be more accurate (average difference of 15\%) and EUROCODE 2 [2] method appears, on average, to be unsafe. The hypothesis test on the $\mathrm{F}_{\text {exp }} /$ $F_{\text {calc }}$ ratio, with a $95 \%$ confidence band, is significantly equal to 1.0 only for the ABNT NBR 9062 [1] method. However, a high standard deviation was also observed in the analysis of the compressive strut failure in corbels with horizontal stirrups.

Next, the same analysis was performed including the strength reduction and/or load factors set for each method. In this case, on average, all design methods provide values lower than those observed in the database, both for tie failure and for compressive strut failure. Taking into account the standard deviation of the $F_{\text {exp }} / F_{\text {calc }}$ ratio the design methods still provide safe values for estimating the tie failure force. This can be confirmed by Figures $8 \mathrm{a}$ and $8 \mathrm{~b}$ where $\mathrm{F}_{\text {exp }} / \mathrm{F}_{\text {calc }}$ ratios above the boundary line, that is in the safety region, were obtained for all of the corbels analyzed. The high standard deviation of the $\mathrm{F}_{\text {exp }} / \mathrm{F}_{\text {calc }}$ ratio for failure of the compressive strut suggested that the value of this ratio was located in the unsafe region from some corbels. This occurred most frequently in corbels without horizontal stirrups and for concrete compressive strengths greater than $60 \mathrm{MPa}$ (Figure 8c). Despite this, the hypothesis test shows that the $\mathrm{F}_{\text {exp }} / \mathrm{F}_{\text {calc }}$ ratio from all the design methods is significantly higher than 1.0 on corbels without horizontal stirrups. The same analysis on corbels with horizontal stirrups shows that all design methods provided values lower than those observed in the database, despite the high standard deviation (Figure 8d). Therefore, it is concluded that the strength reduction and/or load factor values for all the design methods are adequate to ensure safe design of reinforced concrete corbels with and without horizontal stirrups.

\subsection{Assessment of analytical methods}

It has been seen that design methods do not accurately predict the failure force by tie yielding for corbels with horizontal stirrups. Let us now consider the analytical methods proposed by Fernandes and El Debs [4], Hagberg [6] and Campione et al. [7] which take into account the contribution of horizontal stirrups to the corbel strength. Table 2 summarizes the results obtained from the application of analytical methods to the database using a similar methodology as that used for the assessment of the design methods. Figure 9 shows the ratio between failure forces obtained from analytical methods and the experimental results from the database.

Two main assumptions had to be made in order to apply the analytical methods to the database. Firstly, the width of compressive strut in the methods proposed by Fernandes and El Debs [4] and Hagberg [6] was initially taken as $20 \%$ of the effective corbel height $(0.2 d)$. These methods were also analyzed with the compressive strut width determined from the procedure recommended by ABNT NBR 9062 [1]. Secondly, the compressive strut failure force from the method proposed by Campione et al. [7] was determined using the reduction coefficient of concrete strength proposed by these authors. This was 1 . That is, it does not take into account the reduction of the concrete compressive strength on the strut.

It can be noted from Table 2 that the method proposed by Hagberg [6] adequately represented the tie failure force for corbels with horizontal stirrups. The values were, on average, $4 \%$ higher than the experimental values and had low standard deviation. The hypothesis test showed, with a $95 \%$ confidence band, that this is the only analytical method which accurately represents the failure force of the tests $\left(F_{\text {exp }} / F_{\text {calc }}=1\right)$. The other analytical methods overestimated the corbel strength $\left(\mathrm{F}_{\text {exp }} / \mathrm{F}_{\text {calc }}<1\right)$.

The analytical method proposed by Campione et al. [7] overestimated the strength of corbels with horizontal stirrups by $22 \%$, indicating that it was not suitable for these corbels. This is due to high rigidity of the secondary truss proposed in the method which tends to increase the corbel strength when the coefficient $\eta$ decreases. It is suggested, therefore, that the stiffness of the compressive strut on the secondary truss proposed by these authors must be revised. However, the method proposed by Campione et al. [7] showed a good agreement with the experimental results when it was 
Figure 9 - Comparison of analytical methods with experimental results of database

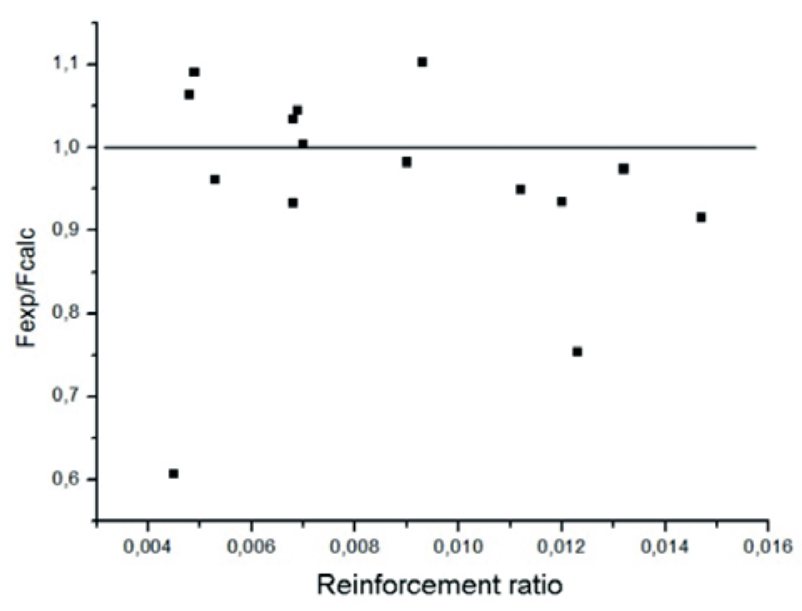

Campione et al. analytical method

A Corbels without horizontal stirrups with failure on tension tie

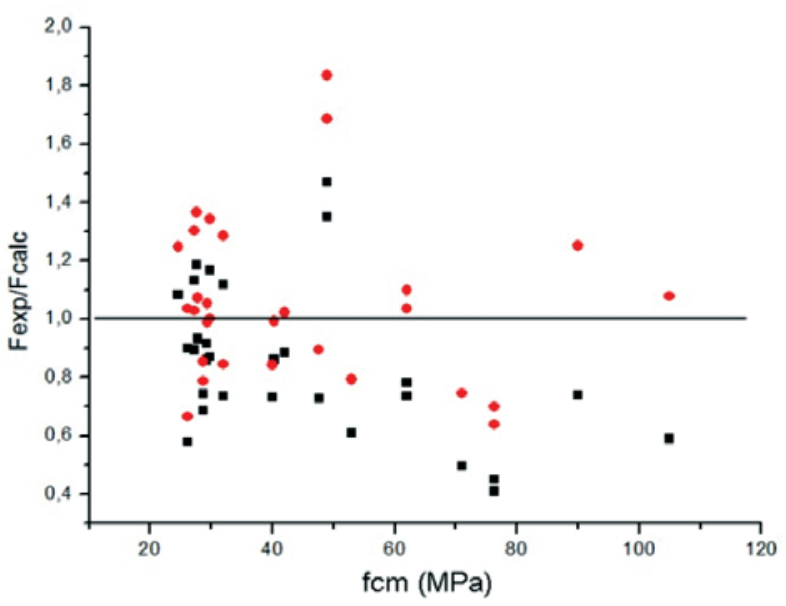

- Campione et al. analytical method- ksi $=1$

- Campione et al. analytical method- ksi from article

Corbels without horizontal stirrups with failure on compressive strut

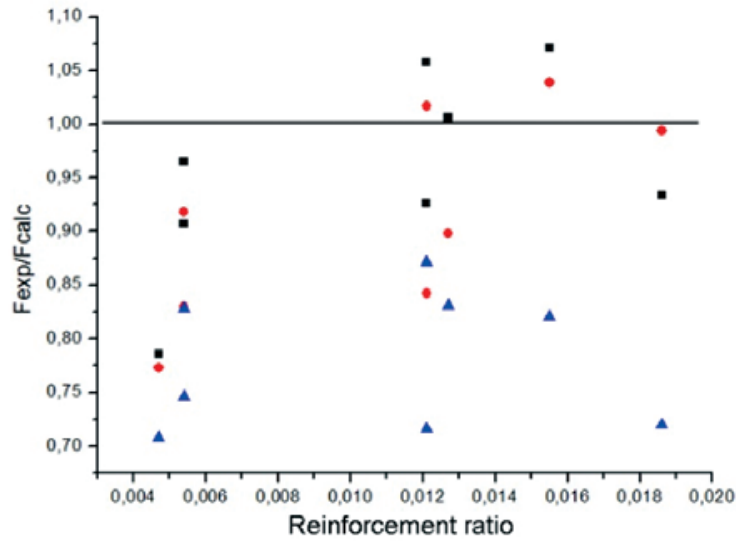

- Hagberg

- Fernandes and El Debs

$\Delta$ Campione et al. analytical method

B Corbels with horizontal stirrups with failure on tension tie

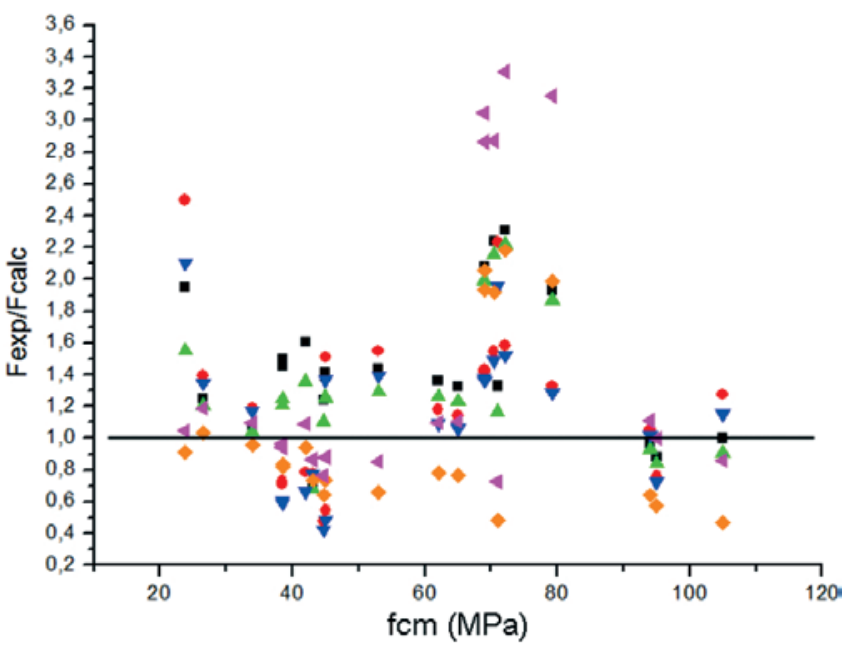

- Hagberg $(\mathrm{hbie}=0.2 \mathrm{~d})$

- Hagberg (hbie from NBR 9062)

$\triangle$ Fernandes and El Debs (hbie $=0.2 \mathrm{~d}$ )

$\checkmark$ Fernandes and El Debs (hbie from NBR 9062)

- Campione et al. - $\mathrm{ksi}=1$

4 Campione et al. - ksi from article

D Corbels with horizontal stirrups with failure on compressive strut 
used to estimate the tie failure force of corbels without horizontal stirrups $\left(\mathrm{F}_{\text {exp }} / \mathrm{F}_{\text {calc }}=1\right.$, with a $95 \%$ confidence band $)$.

The failure force on the compressive strut estimated from the analytical methods proposed by Fernandes and El Debs [4] and Hagberg [6] increases when the fixed value of strut width $(0.2 d)$ was replaced by the strut width defined in ABNT NBR 9062 [1]. In this case the analytically predicted failure force showed a good approach to the experimental results albeit with a high standard deviation.

The analytical method proposed by Campione et al. [7] showed the best accuracy for predicting the failure force limited by concrete crushing on compressive struts for corbels with and without horizontal stirrups. In the absence of the horizontal stirrups, the difference between analytical and experimental results is only $5 \%$ when the coefficient $\xi$ suggested by the authors, $\xi<1$, was used. In the case of corbels with horizontal stirrups a slightly better accuracy of $4 \%$ was obtained when $\xi=1$ was used. This shows the positive effect of horizontal stirrups, which contribute to the confinement of the compressive strut and increase of the failure force. This phenomenon is represented in the analytical method by increasing the value of the coefficient $\xi$.

The width of the compressive strut in the analytical method proposed by Campione et al. [7] is defined by the height of the neutral axis at the interface between the corbel and column $\left(x_{c}\right)$ which is obtained from the flexural theory applied to this section. It is not obtained from the classical strut-and-tie method. Thus, this procedure seems to be more appropriate to apply to corbels without horizontal stirrups or to corbels with few horizontal stirrups. In this case the main tie yields before concrete crushing occurs. This was the major failure mode observed in the database. For this reason, the analytical method of Campione et al. [7] showed the lowest standard deviation when compared to experimental values obtained from the database when compared to other methods. For corbels with horizontal stirrups an increase in the standard deviation was observed.

\subsection{Adjustment coefficients for analytical methods}

An important aspect in the assessment of the analytical methods is the standard deviation value obtained when these methods were compared with experimental results from database. The standard deviation from failure by tie yield was lower than failure by concrete crushing on a compressive strut. This is due to the low variation of the corbels geometry and steel yield strength when compared to the high variation of the compressive strength of concrete. However, the higher standard deviation can be also related to the adopted value of width of the compressive strut in each method, which can be different from the real width on tests.

Therefore, we have determined what adjustment coefficients need to be applied to analytical methods in order to ensure safety levels similar to that of the design methods. For this, the methodology proposed by Ravindra and Galambos [24] was used. This proposed a simplified method for determining strength reduction coefficients for design equations taking into account the desired reliability index. Basically, the reliability of the mathematical method is determined from the probability that the estimated strength given by the mathematical method is higher than the real resistance of corbel. This would obviously be un- safe. Therefore, reduction coefficients $(\phi)$ should be determined which ensure that the resistance provided by the analytical method is always lower than the real resistance for a certain reliability index $(\beta)$.

Based on the simplified method of Ravindra and Galambos [24], and adapted for the analysis undertaken in this work, the strength reduction coefficient $(\phi)$ can be determined using equation (43),

$$
\phi=\frac{F_{\text {exp }}}{F_{\text {calc }}} e^{-\alpha \beta V_{R}}
$$

Where:

$$
V_{R}=\sqrt{V_{M}^{2}+V_{F}^{2}+V_{P}^{2}}
$$

It was proposed by Ravindra and Galambos that the parameter $a$ be set at 0.55 . These authors also proposed a coefficient of variation of $9 \%$ for the material properties $\left(V_{M}\right)$ and $5 \%$ for the geometrical properties $\left(V_{F}\right)$ of the corbels. The coefficient $V_{P}$ is the coefficient of variation i.e. the $\mathrm{F}_{\text {exp }} / \mathrm{F}_{\text {calc }}$ ratio obtained when analytical methods are applied to the corbels database.

From these equations the coefficient $\phi$ can take values less than or greater than unity. When $\phi<1$, the analytical method is determined as being unsafe and it is necessary to reduce the resistance estimated from analytical method by the coefficient $\phi$. If $\phi \geq 1$, this means that the analytical method is safe for the chosen reliability index. In this work a reliability index of 4.5 was chosen. This represents, approximately, a failure probability less than $10^{-5}$.

For the estimation of resistance by design methods, the strength reduction coefficients recommended for each design method were employed. For analytical methods, the safety criterion recommended by the ABNT NBR 8681 [25] was used, that is, the average strength of materials was divided by $\gamma_{c}=1.4$ for concrete and $\gamma_{\mathrm{s}}=1.15$ for steel reinforcement. In addition, the resistance determined by all six methods was divided by $\gamma_{\mathrm{f}}=1.4$ in order to take account, in a simplified way, of the load factors used on structures design. The coefficient $\gamma_{n} \geq 1$ established by the ABNT NBR 9062 [1] for the design of corbels was not used.

From this methodology, and using Tables 1 and 2, we obtain Table 3 which gives the values of the coefficient $\phi$ for each method when failure happen by main tie yielding. This table shows that practically all of the design methods have $\phi>1$ for corbels with or without horizontal stirrup, indicating a failure probability lower than $10^{-5}$. The only exception was when the design method recommended by ABNT NBR 9062 [1] was applied to corbels without horizontal stirrups. However, in this case the coefficient $\phi$ is very close to unity. The analytical methods proposed by Fernandes and El Debs [4] and Hagberg [6] also showed $\phi>1$ indicating a failure probability less than $10^{-5}$ when the coefficients recommended by ABNT NBR 8681 [25] were employed. The Campione et al. [7] analytical method showed $\phi<1$ due to the high standard deviation of $\mathrm{F}_{\text {exp }} / \mathrm{F}_{\text {calc }}$ ratio. Therefore, a strength reduction coefficient of 0.7 to the resistance estimated from this method is suggested to ensure adequate safety. 


\section{Table 3 - Values of the coefficient $\phi$ for methods when failure occurs on tension tie}

\begin{tabular}{|ccc|}
\hline Method & Corbels without horizontal stirrups & Corbels with horizontal stirrups \\
\hline ABNT NBR 9062 (1) & 0.980 & 1.357 \\
PCI (3) & 1.140 & 1.481 \\
EUROCODE 2 (2) & 1.329 & 1.590 \\
Hagberg (6) & - & 1.106 \\
\hline Fernandes and El Debs (4) & - & 1.022 \\
Campione et al. (7) & 0.738 & 0.691 \\
\hline
\end{tabular}

Table 4 shows the values of the coefficient $\phi$ for each method when failure occurs by concrete crushing on the compressive strut. The methods proposed by the PCl [3], Fernandes and El Debs [4] and Hagberg [6] show $\phi>1$ for corbels with horizontal stirrups. In this case the last two methods are safe only when a strut width of $20 \%$ of the effective corbel height was used. In all other cases a strength reduction coefficient $\phi$ must be used in order to ensure a failure probability less than $10^{-5}$. This additional strength reduction coefficient is necessary due to the high values of coefficient $V_{p}$ obtained for the $F_{\text {exp }} / F_{\text {calc }}$ ratio when failure occurs on the compressive strut. However, the coefficient $\phi$ obtained for these analytical methods would be higher if the characteristic strength of materials was used instead of average strength or if a failure probability better than $10^{-5}$ $(\beta<4.5)$ was required.

\section{Conclusions}

This paper describes a comparative analysis of several design methods for precast concrete corbels. For this, six methods, including three methods with horizontal stirrups in their formulation, were compared with a database containing the results for 62 tested corbels available in the literature. From this analysis the main conclusions are:

- For corbels without horizontal stirrups, the design methods of ABNT NBR 9062 [1] and PCI [3] provided the best accuracy when failure occurs by main tie yielding. In this case, the design method of EUROCODE 2 [2] was the most conservative. When failure occurs by concrete crushing on the compressive strut, the $\mathrm{PCl}$ [3] design method was shown to have best agreement with the experimental values from the corbels database. However, a high standard deviation was observed when failure was from the compressive strut.

- For corbels with horizontal stirrups, all design methods underestimated the failure strength of corbels by main tie yielding due to ignoring the contribution of the horizontal stirrups. In this case, the analytical method proposed by Hagberg [6] showed better agreement with the predicted strength.

- All of the methods assessed showed large standard deviations when predicting the failure force of corbels with horizontal stirrups in the database when failure happened on the compressive strut. The method proposed by Fernandes and El Debs [4] with the strut width defined by the ABNT NBR 9062 [1] was the best fit to the failure force from the corbels database. However, the criterion of the ABNT NBR 9062 [1] method for estimating the width of a strut was based only on the load bearing area and not on the maximum compression stress at a nodal zone on the truss geometry. The load bearing area was well defined for the corbels in the database as these were subjected to a vertical load only and have a known bearing-plate. On real precast structures with soft bearings

\section{Table 4 - Values of the coefficient $\phi$ for methods when failure occurs on compressive strut}

\begin{tabular}{|ccc|}
\hline Method & Corbels without horizontal stirrups & Corbels with horizontal stirrups \\
\hline ABNT NBR 9062 (1) & 0.392 & 0.820 \\
\hline PCI (3) & 0.710 & 1.064 \\
\hline EUROCODE 2 (2) & 0.423 & 0.754 \\
\hline Hagberg (6), $h_{\text {bie }}=0.2 d$ & - & 1.302 \\
\hline Hagberg (6), hbie from NBR 9062 & - & 0.848 \\
\hline Fernandes and El Debs (4), $h_{\text {bie }}=0.2 d$ & - & 1.157 \\
\hline Fernandes and El Debs (4), & - & 0.809 \\
\hline$h_{\text {bie }}$ from NBR 9062 & 0.413 & 0.284 \\
\hline Campione et al. (7), with $\xi=1$ & 0.559 & 0.382 \\
\hline
\end{tabular}


the load width support on corbels may be overestimated. In this case the required width of the compressive strut may be overestimated by the Fernandes and El Debs design method if the load width support was not accurately known. For corbels with soft bearings the $\mathrm{PCl}$ [3] design method seems to be the most appropriate for evaluating the failure force of corbels with horizontal stirrups when failure occurs on the compressive strut.

- All design methods with strength reduction and/or load factors estimated a safe failure load with respect to the corbels database with and without horizontal stirrups.

- The method proposed by Campione et al. [7] had the best accuracy for estimating the failure load for corbels in the database without horizontal stirrups. It also had the best accuracy in estimating the failure load from the compressive strut on corbels in the database with horizontal stirrups. This indicates that this method seems to be more appropriate to evaluate the width of strut of corbels in the database.

- All design methods and the analytical methods proposed by Fernandes and El Debs and Hagberg estimated a safe load when failure occurs from yield of main tension tie. However, the reliability index $(\beta)$ of the design methods was higher than 7.5 due to the fact that these methods do not consider the contribution of horizontal stirrups on corbel resistance. Assuming a failure probability of $10^{-5}(\beta=4.5)$, and considering the contribution of horizontal stirrups to the corbel resistance, it may be possible to decrease the tension tie area. Further analysis should be conducted to confirm this possibility, especially adopting more accurate reliability analysis.

- A wide dispersion of estimated failure loads was observed from all methods when failure for corbels in the database was by the compressive strut. Thus the analytical methods that best fit with experimental results were adjusted with a coefficient $\phi$ less than 1.0 in order to ensure adequate safety of these methods. The more conservative methods did not need to be adjusted. The average concrete strength rather than the characteristic strength was adopted in this analysis as the characteristic strength was unknown for the database corbels. Thus the values of the coefficient $\phi$ obtained may be overly conservative. Further analysis should be carried out, in particular by adopting more accurate reliability analysis that considers the variability of strength of concrete and steel, as well as variability of geometry and loading.

Finally, we must emphasize the importance of checking the accuracy of analytical methods in representing physical phenomena as they are directly related to the safety of structure designs. This can be checked by comparing the predictions of the analytical methods against experimental results, as done in this paper. To do this, however, it is necessary to have an extensive database for evaluating the variability of material strengths and even the test method. Unfortunately, this is not always available.

\section{Acknowledgements}

The authors wish to thank the Brazilian National Council of Research and Development (CNPq) for financing this research (Project number 552118/2011-7) and for granting a scholarship for the authors.

\section{Notation}

$A_{s}$ : Area of steel bar:

a: Distance from the vertical load applied to the corbel and column face;

b: Corbel width;

c: Corbel length;

c': Corbel length less concrete covering and diameter of tension tie;

$\phi$ : Diameter of bar anchor on the end tension tie;

$\mathrm{c}_{\mathrm{c}}$ : Concrete covering at the end of the tension tie;

$\mathrm{d}$ : Distance from extreme compression fiber to centroid of tension tie;

$E_{c}$ : Modulus of elasticity of concrete;

$E_{s}$ : Modulus of elasticity of reinforcement steel;

$F_{\text {bie }}$ : Force acting in a strut;

$f_{c d}$ : Design compressive strength of concrete;

$f_{c k}$ : Characteristic compressive strength of concrete;

$f_{y d}$ : Steel yielding stress, calculus value;

$h_{\text {bie }}$ : Width of strut;

$h_{c}$ : Width of column;

$\mathrm{k}_{1}$ : EUROCODE 2 constant, that is 1.18;

l: Horizontal length of strut;

$\mathrm{n}$ : Number of horizontal stirrups on the corbel;

$\mathrm{R}_{\mathrm{sd}}$ : Resultant force in the tension tie;

$\mathrm{R}_{\mathrm{cd}}$ : Resultant force on compressive strut;

$\mathrm{V}_{\mathrm{d}}$ : Failure load of corbel;

$\beta_{n}$ : Coefficient recommended by the $\mathrm{PCl}$, that is: 1.0 for a nodal zone that receives only compressive forces; 0.8 for a nodal zone with one tie; 0.6 for a nodal zone with more than one tie;

$\beta_{s}$ : Coefficient recommended by the $\mathrm{PCl}$, that is: 0.6 for corbels without horizontal stirrups and 0.75 for corbels with horizontal stirrups;

$\gamma$ : $\quad$ Strength reduction factor recommended for $\mathrm{PCl}$;

$\gamma_{c}$ : Strength reduction factor for concrete;

$\theta$ : Angle of strut;

$\xi: \quad$ Reduction coefficient for confined concrete strength;

$\sigma_{\text {cd }}$ : Compressive stress on strut.

\section{References}

[1] ASSOCIAÇÃO BRASILEIRA DE NORMAS TÉCNICAS ABNT. NBR 9062: Design and execution of precast concrete structures. Rio de Janeiro, 2006 (In Portuguese).

[2] COMITÉ EUROPÉEN DE NORMALISATION. EUROCODE 2: Design of concrete structures - Part 1.1: General rules and rules for buildings. Brussels, Belgium, 2004.

[3] PRECAST/PRESTRESSED CONCRETE INSTITUTE PCI. PCI Design Handbook. 7th Edition, 2010.

[4] FERNANDES, R. M.; EL DEBS, M. K. Análise da capacidade resistente de consolos de concreto armado considerando a contribuição da armadura de costura. Cadernos de Engenharia de Estruturas, São Carlos, v.7, n.25, 2005; p.103-128 (In Portuguese).

[5] LEONHARDT, F.; MÖNNIG, E. Construções de concreto: Casos especiais de dimensionamento de estruturas de concreto armado. v.2.1., Rio de Janeiro: Interciência, 1978 (In Portuguese).

[6] HAGBERG, T. Design of concrete brackets: on the 
application of the truss analogy. ACl Journal, v.80, n.1, 1983; p.3-12.

[7] CAMPIONE, G.; LA MENDOLA, L.; PAPIA, M. Flexural behaviour of concrete corbels containing fibers or wrapped with FRP sheets. Materials and Structures, v.38, 2005; p.617-625.

[8] FATTUHI, N. I. Strength of SFRC corbels subjected to vertical load. Journal of Structural Engineering, v.116, n.3, 1990; p.701-718.

[9] FATTUHI, N. I. Column-load effect on reinforced concrete corbels. Journal of Structural Engineering, v.116, n.1, 1990; p.188-197.

[10] FATTUHI, N. I.; HUGHES, B. P. Ductility of reinforced concrete corbels containing either steel fiber or stirrups. $\mathrm{ACl} \mathrm{Ma}-$ terials Journal, v.86, n.6, 1989; p.644-651.

[11] FATTUHI, N. I. Reinforced corbels made with high-strength and various secondary reinforcements. $\mathrm{ACI}$ Structural Journal, v.91, n.4, 1994; p. 376-382.

[12] FATTUHI, N. I. Reinforced corbels made with plain and fibrous concrete. ACI Structural Journal, v.91, n.5, 1994; p.530-536.

[13] FATTUHI, N. I. Strength of FRC corbels in flexure. Journal Structural Engineering, v. 120, n.2, 1994; p.360-377.

[14] FOSTER, J. S.; POWELL, R. E.; SELIM, H. S. Performance of high-strength concrete corbels. ACI Structural Journal, v.93, n.5, 1996; p.555-563.

[15] KRIZ, L. B.; RATHS, C. H. Connections in precast concrete structure: strength of corbels. Journal Prestressed Concrete Institute, v.10, n.1, 1965; p.16-61.

[16] OLIVEIRA, E. M. Consolos de concreto moldados em duas etapas: Influência do tratamento da interface e da adição de fibras de aço. 2012. Dissertação (Mestrado em Engenharia Civil) - Programa de Pós-Graduação em Geotecnia, Estruturas e Construção Civil, Universidade Federal de Goiás, Goiânia, 2012 (In Portuguese).

[17] LANDIM, B. P. B. C.; CASTRO, C. G. Dimensionamento e análise experimental de consolos de concreto moldado em duas etapas. 2014. Monografia (Trabalho de Conclusão de Curso de graduação em Engenharia Civil) - Departamento de Engenharia, Pontifícia Universidade Católica de Goiás, Goiânia, 2014(In Portuguese).

[18] HERMANSEN, B. R.; COWAN, J. Modified shear-friction theory for bracket design. ACI Journal, v.71, n.7, 1974; p.55-60.

[19] BIRKLE, G.; GHALI, A.; SCHÄFER, K. Double-headed studs improve corbel reinforcement. Concrete International, v.24, n.9, 2002; p.77-84.

[20] MATTOCK, A. H.; CHEN, K. C.; SOONGSWANG, K. Design proposals for reinforced concrete corbels. Journal Prestressed Concrete Institute, v.21, n.3, 1976; p.18-42.

[21] TORRES, F. M. Análise teórico-experimental de consolos de concreto armado. 1998. Dissertação (Mestrado em Engenharia de Estruturas) - Escola de Engenharia de São Carlos, Universidade de São Paulo, São Carlos, 1998(In Portuguese).

[22] JACOBS, J.P. EUROCODE 2: Worked examples. Belgium: European Concrete Platform ASBL, 2008.

[23] CANHA, R. M. F.; KUCHMA, D. A.; EL DEBS, M. K.; SOUZA, R. A. Numerical analysis of reinforced high strength concrete corbels. Engineering Structures, v.74, 2014; p.130-144. (http://dx.doi.org/10.1016/j.engstruct.2014.05.014 )
[24] RAVINDRA, M. K.; GALAMBOS, T. V. Load and resistance factor design for steel. Journal of the Structural Division, v.104, n.9, 1978; p.1337-1353.

[25] ASSOCIAÇÃO BRASILEIRA DE NORMAS TÉCNICAS ABNT. NBR 8681: Actions and safety of structures - Procedure. Rio de Janeiro, 2003 (In Portuguese). 